講 演

環境保全への国際的取り組み*

$$
\text { 中西聡 }{ }^{* *}
$$

(Received January 13, 2007 : accepted March 9, 2007)

\title{
International Cooperation in Environmental Protection
}

\section{Satoshi Nakanishi}

\begin{abstract}
To reduce damage to the environment, both locally and globally, while meeting the rising demand for oil is a big challenge for oil companies. This presentation explores what has been done to protect the environment in Sakhalin II and Canadian oil sands projects, touching on the complexity of environmental issues and important roles which oil companies should play.

Of the many environmental issues faced today, the risk of global climate change is now growing and generates enormous public interest. In the meantime, oil is projected to maintain a major position in supplying primary energy for a long time to come. To tackle this problem, increases in energy efficiency and a shift to non-fossil fuels are of utmost importance.

Along with these measures, gas flaring reduction and carbon capture and storage (CCS) are also very effective ways to reduce global warming gas emissions.

In spite of the efforts taken by individual oil companies, the amount of global gas flaring still remains at a high level because of several constraints encountered in flaring countries. While CCS is a very promising option for drastically reducing emissions if applied at large power plants which burn fossil fuels, there is still a long way to go for this option to be accepted as a reliable and affordable means.

This presentation reviews international efforts to promote these two measures and provides information on how they are progressing in Russia, Nigeria, Canada and the EU.

Lastly, the presentation highlights some specific topics in related international carbon reduction efforts including CDM, CCS EOR, emissions trading and increasing public awareness in environmental issues.

The concluding message is that the challenge for sustainable energy development in the new century has already started, and the roles of oil companies are essential as a main player in the high energy society.
\end{abstract}

Key words : $\quad$ sustainable energy development, gas flaring reduction, carbon capture and storage, CDM, CCSEOR

\section{1. はじめに}

開発と環境保全の両立は社会の重大テーマであり，な かでも石油・ガスなど化石燃料の開発・消費が拡大し， その結果引き起こされる環境破壊への懸念が大きくなつ

*平成 18 年 10 月 31 日, 平成 18 年度石油技術協会秋季講演会「地 球環境にやさしいエネルギー開発技術」(〜石油開発における 環境保全への取り組み〜) にて講演 This paper was delivered at the 2006 JAPT Autumn Meeting entitled "Environment \& Energy Development - Challenges for Environmental Management in the Oil Industry" held in Tokyo, Japan, October 31, 2006.

** (財) 日本エネルギー経済研究所アジア太平洋エネルギー研究 センター The Institute of Energy Economics, Japan, Asia Pacific Energy Research Centre

Copyright (C) 2007, JAPT
てきている。この問題への取り組みは新技術への挑戦で あると同時に, 多くのステークホルダーが絡む複雑で困 難な課題でもある。そのなかで, 開発の当事者である石 油開発会社が果たす役割と社会的責任は大きく, 問題解 決に向けて積極的な活動が求められるようになってきて いる。その範囲は石油・ガスの開発現場の生態系や水の 保全という地域的環境問題のみならず，化石燃料の大量 使用の結果引き起こされる地球温暖化という地球規模の 環境問題も含まれるであろう。

本講演では地域的環境問題の事例としてサハリン II とカナダオイルサンド開発プロジェクトをとりあげ, 環 境問題の複雑さと石油開発会社に求められている社会的 責任の大きさについて述べる。カナダオイルサンドに代 
表される非在来型石油資源は，在来型と比較し生産によ り多くのエネルギーの投入が必要であることから炭酸ガ スの排出が多く, その開発には地球温暖化問題も内在し ている。次に世界の一次エネルギー供給・炭酸ガス排出 量の予測を紹介し, 化石燃料は今後中期的に一次エネル ギ一供給源として支配的な地位を占め続ける見通しであ り, 長期的にもその可能性があること, この結果, 地球 温暖化がますます進展し将来とり返しのつかない深刻な 環境破壊がもたらされる脅威が高まっていることについ て触れる。そして, 省エネルギー, 非化石燃料の開発促 進が重要であると同時に, 現在も増大しつつある二酸化 炭素 $\left(\mathrm{CO}_{2}\right)$ の排出削減が緊急課題になってきていることに ついて述べる。次に具体的な温暖化ガス排出削減策であ るフレアガスの削減, $\mathrm{CO}_{2}$ の地下固定について, 最近の世 界の動向とその具体的な取り組みの現状について述べる。 前者についてはロシアとナイジェリアの事例を, 後者に ついてはカナダ, 欧州での事例を取り上げる。最後に地 球規模の環境問題に対する, 国際的な取り組みの重要性, 石油開発会社が今後果たすべき役割について述べる。

\section{2. サハリン II 開発プロジェクト}

サハリン II プロジェクトは 1999 年にフェーズ 1 の暫 定生産（夏季限定の原油生産）が開始され，現在，2008 年開始を目標としてフェーズ 2 本格生産（原油日量 18 万バレル, LNG 年産 960 万トン) に向けて工事が進行 している。本プロジェクトはロシアにとつて初の LNG プロジェクト, 欧州以外へのガス販売マーケットの開 発, 日本にとっては, エネルギー供給先の多角化という 視点から重要であり，大きな期待と関心が寄せられてい る。同時に本プロジェクトは豊かな自然が残されている
地域での本格的開発となることから，環境保全への取り 組みは国際環境 NGO の厳しい監視の対象となってきた (図 1 参照)。海上パイプライン敷設とコククジラの保 護, 陸上パイプライン敷設と河川・サケ産卵場の保護, 水海への流出油対策等が主だった環境問題として挙げら れる。問題の解決のためには，1）環境影響調査を早期 に実施し, 影響を回避・最小化する代替案や緩和策をと る，2）住民，環境 NGO，プロジェクト資金を融資する 銀行などすべてのステークホルダーに十分な情報開示を 行う,3) 環境配慮が十分でないと指摘があった場合には, ステークホルダーが協議・検討する場を設けることが重 要である。

開発と環境保全を巡つては多様な意識, 対立する意見 があり，その立場によって Shell をオペレーターとする 本プロジェクト事業者（Sakhalin Energy Investment Co. : SEIC）の環境配慮についての評価は大きく異なる。

2003 年に予備的環境影響評価に基づきフェーズ 2 プ ロジェクトの開始宣言がなされた。しかし，コククジラ の保護対策が不十分との指摘を受けたことから, 環境影 響評価が再度実施され，初期のパイプライン敷設ルート を見直してコククジラへの影響がより少ない敷設ルート が選定された（図 2 参照）。また，1,000 箇所を超える陸 上パイプラインの河川横断工事については, 影響を最小 限にする工法が選択され, すべての箇所の工事計画情報 がウェブサイトに公開されている (図 3 参照)。十分な 環境配慮への要請はプロジェクト資金を融資する欧州復 興開発銀行 $(\mathrm{EBRD})$, 国際協力銀行 (JBIC) などからも 出されている。プロジェクトコストは当初の 100 億ドル から 200 億ドルへと大幅増加が発表されているが, 環境 配慮による影響もかなりあることが想像される。

\begin{tabular}{|c|c|}
\hline 1999 年 7 月 & フェーズ 1 生産, 出荷開始。 \\
\hline 1999 年 10 月 & 貯油タンカー係留装置の索綱切断事故。生産一時停止。 \\
\hline 2001 年 12 月 & 予備的「環境影響評価」（EIA）説明会実施 \\
\hline 2003 年 1 月 & $\begin{array}{l}\text { 国際環境 NGO,SEIC へ環境要望書提出 } \\
\text { (コククジラ保護，PL の安全性，流出油の危険性，掘削屑の投棄等) } \\
\text { 「公開諮問 / 情報公開プラン」を発表 }\end{array}$ \\
\hline 2003 年 3 月 & $\begin{array}{l}\text { サハリン縦断 PL の技術説明書公開（アラスカ PL との比較） } \\
\text { NGO 指摘の油流出対策に関する問題点に回答 }\end{array}$ \\
\hline 2003 年 5 月 & フェーズ 2 開始宣言 \\
\hline 2003 年 10 ～ 11 月 & 「環境, 社会, 健康に対する影響評価」説明会開催 \\
\hline 2003 年 12 月 & 「公開諮問 / 情報公開プラン」説明会開催 \\
\hline 2004 年 4 月 & EBRD 総裁, SEIC の取り組みに不満足と発言 \\
\hline 2004 年 5 月 & 国際環境 NGO，世界の大手民間銀行に問題点を警告 \\
\hline 2005 年 12 月 & $\mathrm{EBRD}$, フェーズ 2 の「環境, 社会」配慮は妥当と評価 \\
\hline 2006 年 9 月 & ロシア天然資源省, 事業の一部認可を取り消し \\
\hline
\end{tabular}

図 1 サハリン II の環境問題を巡る動き

(出典 : Sakhalin Energy Investment Company Home Page) 

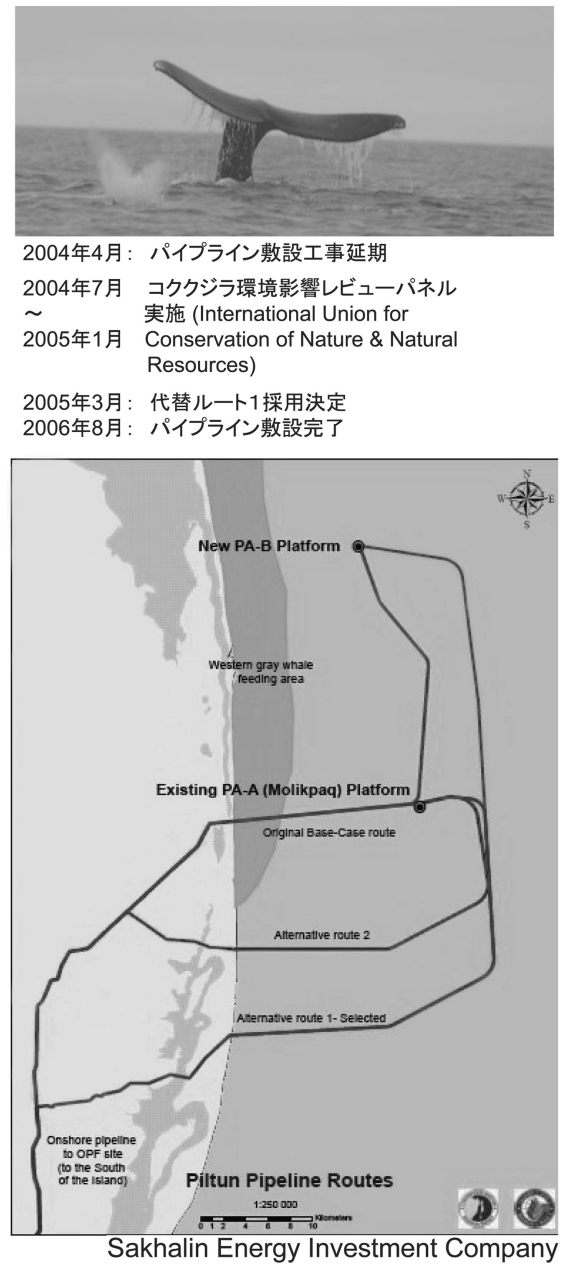

図 2 海上原油パイプライン敷設工事とクジラ保護

海上パイプライン敷設工事はすでに完了し，陸上パイ プラインの河川横断工事の大半が終了した 2006 年 9 月, ロシア天然資源省は環境対策が不十分だとして突然，事 業の一部認可を取り消した。同省は陸上パイプライン 敷設に当たり森林を認められた以上に切ったなどの違 反をその理由に挙げており，開発事業者もそのような不 手際が一部あったことを認めている。ロシア政府の行動 は Gazprom のサハリン II プロジェクト参加比率交渉を 巡る政治的動機に基づくもので，環境問題は口実として 使われたとの見方がもつぱらである。SEIC は改善を約 束しており，「環境配慮が不十分との指摘を受けた場合， ステークホルダーが協議・検討する場を設ける」いう基 本事項を実行している。環境配慮に重大な過失があった とはいえないのではないだろうか。

SEICが運営するウェブサイトには，ほかのプロジェ クトには見られないほど多くの情報が公開されている。

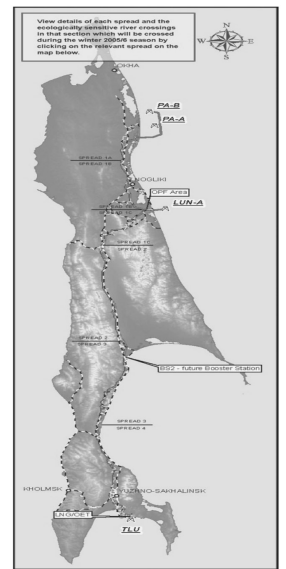

油ライン: $20 "$

ガスライン: $20 " / 30 "$
ROW: $36-66 \mathrm{~m}$

横断河川: 約 1,100

2004年1月:旉設開始

2006年9 月: $80 \%$ 敷設完了

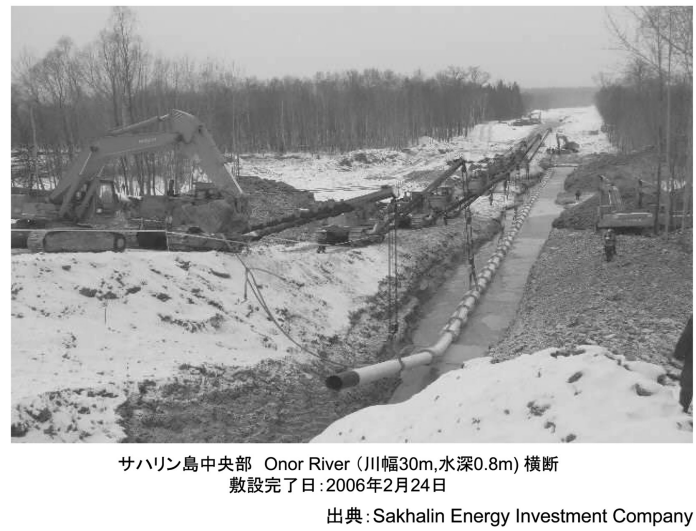

図 3 Sakhalin II 陸上パイプラインと河川保護

開発と環境が社会全体に受け入れられる形で両立するた めには，情報公開が鍵であることを考えると, 開発事業 者の社会的責任は十分に果たしていると思われる。情報 公開の多さがかえつてプロジェクトの遅延を招いたとの 悪口が聞こえるような気もするが，石油開発会社に対し て, 開発に伴う環境保全への社会的責任を求める声は今 後ますます強くなっていくのではないだろうか。

\section{3. カナダオイルサンド}

EIA Annual Energy Outlook 2006 によるとカナダオイ ルサンドは現在, 日量 1 百万バレルの生産レベルに達 し，減退を始めた同国の在来型石油をカバーする重要な エネルギー資源の位置を占めている。2030 年には日量 3.6 百万バレルへ伸びると予測されている（図 4 参照）。 2004 年には回収可能な埋蔵量として 1,700 億バレルが計上 され, 究極可採埋蔵量は将来的に 3,000 億バレルまで増加 すると見込まれている。カナダのオイルサンドのポテン シャルはサウジアラビアの原油埋蔵量に匹敵するほどで あり，その将来には大きな期待が寄せられているが，一 


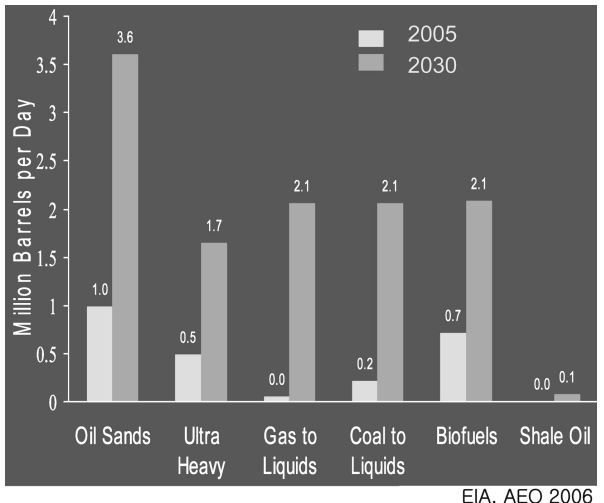

図 4 世界の非在来型石油の生産予測

方で解決しなければならない環境問題も抱えている。

現在，オイルサンドは主に露天掘りによって生産され ている。その方法が適用できるサイトはあと 2,3 箇所で 飽和し，今後，in-situ プロジェクトが増加するが，2015 年まではオイルサンド生産の主流の座を占めると予測さ れている。露天掘りサイトは開発の爪痕であり，採掘終 了後は跡地を埋め戻し元の状態に戻すことが義務付けら れている (図 5 参照)。Suncor 社の露天掘りサイトの総 面積は 9,654 ha，埋め戻し面積は 858 ha（8.9\%）であり， 今後, 長期計画に基づく表土の現状復帰を重要課題とし ている (同社 Annual Report 2005)。オイルサンドの生産・ 処理には大量の水が必要で, 川から取水している。露天 掘りでは, 1 バレルのオイルサンドの生産に 10 バレル の水, in-situ では 3 バレルの水が必要とされる。使用さ れた水はサンドや油分などの残椬を取り除いたのち川に 戻されるが，現在では $85 \%$ の水が生産に再使用されて いる。今後, 取水量の増加を抑えるため, 水の再使用率 の向上が目標となっている。生産基地の近くにできた水 処理のための巨大な池（tailing pond）も開発の傷跡であ
り, ふかふかになつた土壌の改良も含めていずれ元の状 態に戻す計画になっている (図 6 参照)。

オイルサンド 1 バレルの生産にはそのエネルギー量の $1 / 3$ のガスが水蒸気の生成, オイルサンドのアップグレー ディングなどに必要である。これは産出・投入エネルギー 比（Energy Return of Investment：EROI）が在来型石油 と比較してかなり低いことを意味する。カナダにおける 近年の地球温暖化ガス排出増の多くはオイルサンド産業 からのものであり，オイルサンド産業の負の側面となつ ている。

カナダ政府のエネルギー予測 (The Reference Case 2006. Natural Resources Canada）によると, カナダの 地球温暖化ガス総排出量 758 百万トン（炭酸ガス換算, 2004 年）は, 今後 828 百万トン（2010 年), 897 百万卜 ン（2020 年）へと大きく増加すると見込まれている（図 7 参照)。このままでは京都議定書数値目標（563 百万卜 ン）の達成が不可能なことは明白であり, カナダ政府は 京都議定書離脱も選択肢の 1 つとして考えているなど, 対策に苦慮しているといわれている。連邦政府は京都議 定書の目標を達成する義務を負つているが, エネルギー・ 環境政策は州政府に任されていることから, 目標達成計 画の策定は連邦政府, 州政府および産業などのステーク ホルダーの協議を通して行われている。炭酸ガス地中隔 離 (Carbon Capture \& Storage:CCS) は対策の有力オプショ ンの 1 つであり, CCS に対する連邦政府, 州政府の優遇 策もすでに示されている。Suncor 社は CCS に積極的な 姿勢を示している。今後, $\mathrm{CO}_{2} \mathrm{EOR}$ プロジェクトとして の適用 (CCSEOR) に向けて, 石油開発会社の積極的対 応が求められるようになることが予想される。

オイルサンドの開発は地域的環境問題のみならず, 地 球規模の環境問題も内在している。これは, 将来, 開発 が期待されているが EROIの低い超重質油, オイルシェー

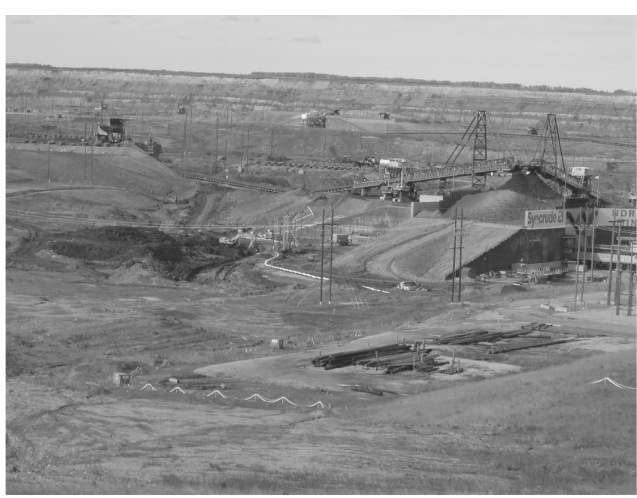

オイルサンド採掘現場

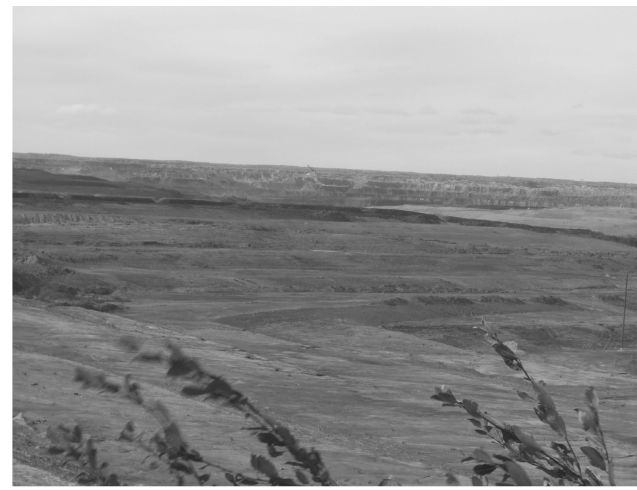

採掘終了後の表土埋め戻し現場

Suncor 社の実績 $(1967-2005)$

総採掘面積: 9,654 ha、埋め戻し面積: 858 ha (8.9\%)

図 5 オイルサンド採掘現場 

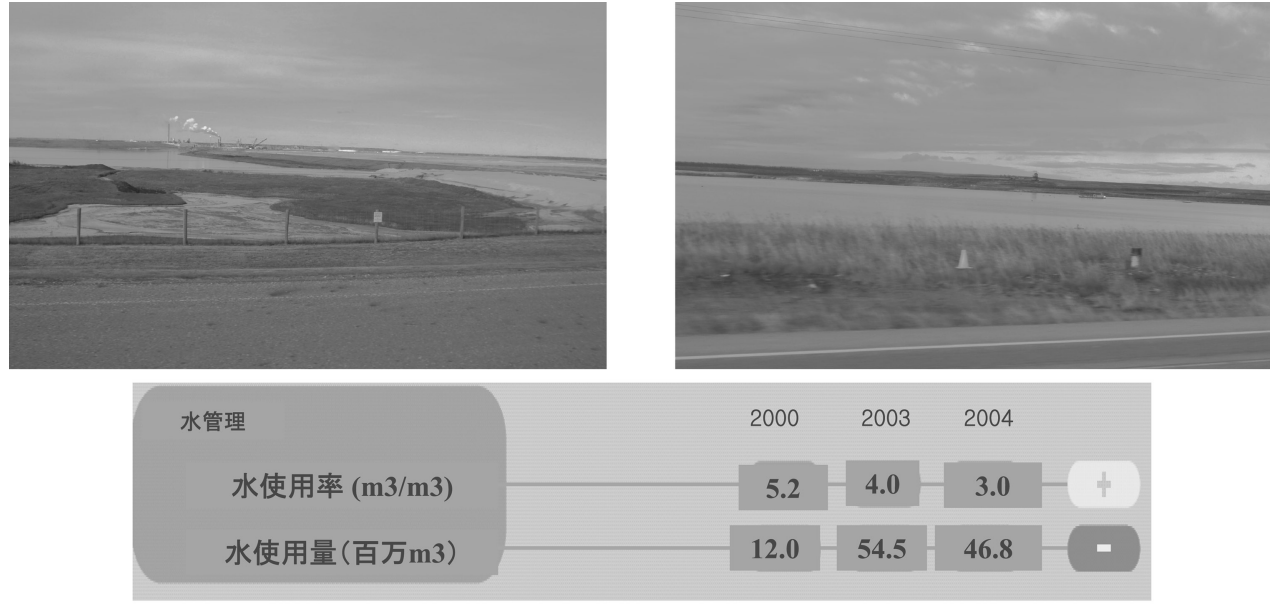

Suncor Annual Report 2004

図 6 オイルサンド, 処理水再利用

\section{Figure EMl \\ Total GHG Emissions}

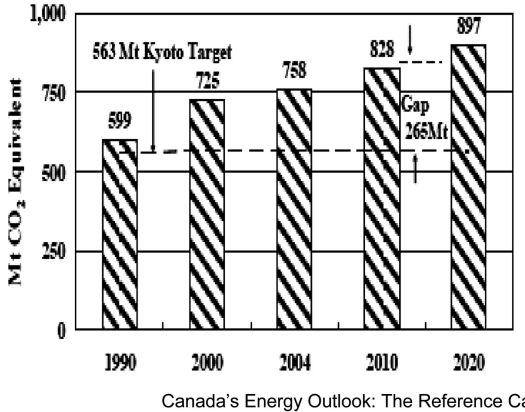

Table EM1

Changes to Annual Emissions by Sector (Mt)

$\begin{array}{cc}2004- & 2010- \\ 2010 & 2020\end{array}$

\section{Sector}

Upstream Oil and Gas $\quad 7 \quad-10$

Upgrading synthetic crude

oil

Refining (heavier grades of crude oil)

Electricity

Industrial

Commercial and

Residential

Transportation

Other

Total

2006 Natural Resources Canada
$27 \quad 19$

$7 \quad 6$

$1 \quad-4$

$4 \quad 8$

$1 \quad 13$

$16 \quad 25$

$8 \quad 11$

図 7 カナダオイルサンド $\mathrm{CO}_{2}$ 排出量

ルにとっても共通の課題である。

\section{4. エネルギー需要の増大と地球環境破壊}

国際エネルギー機関（IEA）の見通しによると，世界 の一次エネルギー需要（2004 年）11,204 Mtoe は基準シ ナリオで 2030 年までに $50 \%$ 強増加すると予測されてい る (年率平均 $1.6 \%$ 増)。需要増の $70 \%$ 以上は開発途上 国によるものであり，中国だけで $30 \%$ を占める。化石 燃料はこの間のエネルギー需要増の大部分を占めるた め，世界需要に占めるシェアは現状の $80 \%$ を維持する と予測されている。石油需要も 2005 年の日量 84 百万バ レルから日量 99 百万バレル（2015 年），日量 116 百万バ レル（2030 年）へと拡大する。

これに伴い，世界のエネルギー起源の $\mathrm{CO}_{2}$ 排出量は 2004 年の 260 億トン（炭素換算 70 億トン） から 55\%
増加し（年率平均 $1.7 \%$ 増), 400 億トンに達する（IEA World Energy Outlook 2006)。

図 8，9 は Battelle 研究所が実施した今世紀末までの超 長期予測結果で, 世界の一次エネルギーの需要増と化石 燃料の優位性が今世紀末まで続き, その結果, $\mathrm{CO}_{2}$ の排 出量が飛躍的に増加するシナリオが示されている。2030 年までの予測はIEAのものとおおむね一致している。(工 ネルギーは exaJule 表示で, $1 \mathrm{EJ}=24$ Mtoe.。 $\mathrm{CO}_{2}$ 排出量 は炭素換算 tera gram 表示で, 1,000 tera gram = 10 億トン)

現在すでに地球温暖化がもたらす環境破壊のリスク が顕在化しており, 省エネによってエネルギーの需要増 を抑えることが急務になっている。また，エネルギー供 給の安全保障, 供給源多角化の観点から, 原子力, 太陽 光風力などの自然エネルギー, バイオ燃料の開発促進も 重要な代替オプションとなっている。この結果, 強力な 


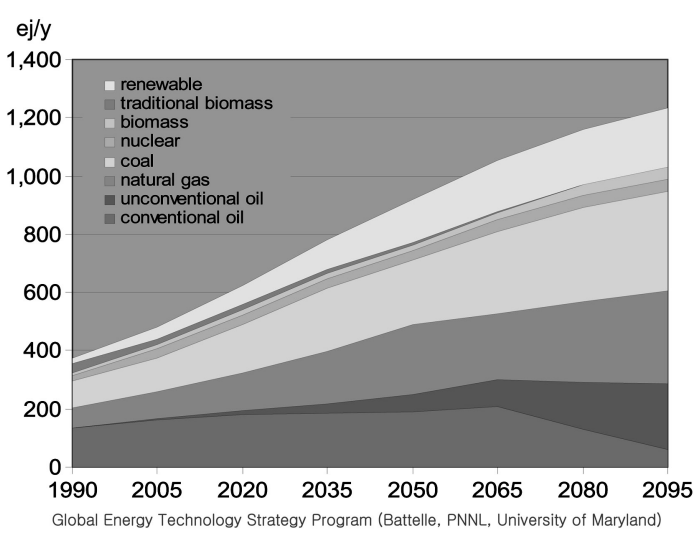

図 8 世界の一次エネルギー供給予測

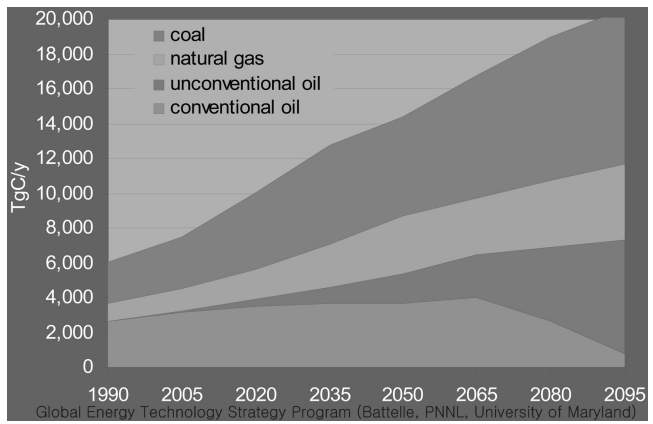

図 9 世界の $\mathrm{CO}_{2}$ 排出量予測

エネルギー政策，新技術の発展によっては将来，クリー ンエネルギーが大きく進展していることも十分考えられ る。反対に化石燃料のうち石油は石炭と比較して相対的 に資源量が少ないため，今後の探鉱開発の進展いかんに よっては将来一次エネルギ一供給源としての主要な地位 を失う可能性も否定できない。シナリオプラニングは将 来の姿を考えるための有効な道具であり，エネルギーの 将来を考えるに当たつては長期的視点が重要である。化 石燃料が超長期間にわたつて使われ続けるシナリオも思 考実験の 1 つして考慮する価值は十分にあるであろう。

図 10 は $\mathrm{CO}_{2}$ 排出量抑制目標を図 9 の化石燃料の優位 性が今世紀末まで続く場合の排出量と対比して示してい る。世界の気候変動研究者のほぼ一致した意見によると, 地球温暖化による気候変動リスクを回避するためには, すでに産業革命前の 280 ppm から 380 ppm まで増加して いる大気中の $\mathrm{CO}_{2}$ 濃度を, ベースラインの 2 倍程度, す なわち $550 \mathrm{ppm}$ に抑える必要があるとしている。この図 は現時点から $\mathrm{CO}_{2}$ 排出量の増加を抑え，2035 年頃に炭 素換算 100 億トン $\left(\mathrm{CO}_{2}\right.$ 換算 370 億トン) をピークとして, その後, 排出量を減少トレンドに転換させる必要性を示 している。2030 年時点の排出削減必要量は約 10 億トン

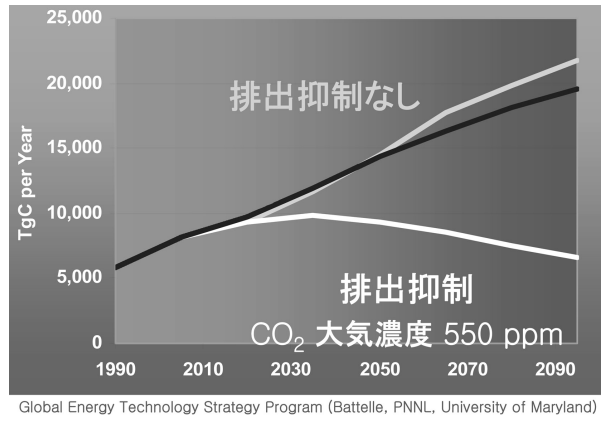

図 $10 \quad \mathrm{CO}_{2}$ 排出量抑制目標

$\left(\mathrm{CO}_{2}\right.$ 換算 37 億トン $)$ と読み取れる。対策が遅れれば遅 れるほど排出量抑制目標の達成は困難になり, $\mathrm{CO}_{2}$ 濃度 がベースラインの 3 倍, すなわち, 840 ppm に達すると, グリーンランドや南極の水が解けて海面が大幅に上昇す る結果, 深刻な地球環境破壊のリスクが高まると警告さ れている。

エネルギー起源の $\mathrm{CO}_{2}$ 排出量削減のためには, フレ アガスの削減が必要であり, $\mathrm{CO}_{2}$ の回収・固定が不可欠 である。 $\mathrm{CO}_{2}$ の回収・地下固定は石油開発技術と関連が 深く, 技術開発とプロジェクトの実施に当たつて石油開 発会社の果たす役割は大きい。

\section{5. フレアガスの削減への取り組み}

原油の生産現場においてフレアされているガス量は 全世界で年間 $150 \mathrm{BCM}$ （435 百万トン $\mathrm{CO}_{2}$ 換算）と推 定されている (Global Gas Flaring Reduction Partnership Report)。イラク, イラン, ナイジェリア, ロシアで特 に多く, これら 4 カ国で 60 BCM のガスがフレアされて いる。石油開発会社はガス資源の浪費を減らする努力を 続けてきているがその成果は限定的であり, 過去 20 年 間, 世界のフレア量はほぼ同じ高いレベルに留まってい る。この原因としては石油生産の増加に伴う随伴ガス量 の増加, ガスの有効利用を促進する市場・インフラ整備 の遅れ，フレア削減プロジェクトに必要な資金の不足な どが挙げられる。一方, アブダビのように世界的な環境 意識の高まりからガスフレアリングが厳しく規制され， 具体的な基準を示す細則の整備が進んでいる国もある。

図 11 はフレアガス削減を巡る最近の動向を示す。

Global Gas Flaring Reduction Partnership（GGFR）は 産油国政府, 国営石油会社, International Oil Company (IOC) などをパートナーとする官民協力機構で, グロー バルな知識・情報の共有化によってフレアガス削減に向 けての障害を克服し, 各国の削減プロジェクトの推進を 支援することを目的として 2002 年に設立された。カナ 
- Global Gas Flaring Reduction (GGFR) Partnership 設立 (2002 年 8 月)

- 2nd International Gas Flaring Reduction Conference, Algeria（2004 年 5 月)

- Rang Dong No Gas Flaring CDM 認証取得 (2006 年 2 月)

- Russia - EU Technology Center Round Table Meeting (2006 年 6 月) “Associated gas utilization: removal of barriers and attraction of investments"

- St. Petersburg G8 Summit (2006 年 7 月) フレアガス削減の重要性を確認

図 11 フレアガス削減を巡る最近の動向

ダ， $\mathrm{EU}$ ，ノルウェー，イギリス，米国は資金提供者と して参加し，石油会社では BP, Chevron, ENI, ExxonMobil, Marathon Oil, Hydro, Shell, Statoil, TOTAL が，産油国では Algeria (Sonatrach), Angola (Sonangol), Cameroon, Chad, Ecuador, Equatorial Guinea, Indonesia, Kazakhstan, KhantyMansijsyk (Russian Federation) がパートナーとして名を 連ね, OPEC，世界銀行も参加している。

GGFR の第 2 回年次会議が開かれたアルジェリアは長 年にわたり，世界のフレアガスランキング上位国である が，近年，資源保護，環境保全の観点からフレアガスの 削減に力を入れており，2010 年までにゼロフレアリン グを達成することを目標としている。

Russia -EU - Technology Centre はロシアと EU 間の対話 組織で，エネルギー技術の相互協力とエネルギー部門へ の投資推進を目的としている。本年 7 月，サンクトペテ ルブルグで開催された G8 サミット開催に先立ち，ロシ アの随伴ガスの利用をテーマとした会議が開催された。 ロシアでは随伴ガスの利用を阻害する要因が多く大量の 随伴ガスがフレアされているが, ガス市場の改革を進め, 京都メカニズムの活用によってガスの有効利用を図ろう とする機運が高まっている。

ガスフレアリングの削減は地球温暖化ガスの排出を抑 制し地球環境を保護する取り組みでもあり，石油開発会 社が果たすべき社会的責任は今後, 大きくなっていくで あろう。将来的には，ガスフレアリング対策が解決でき なければ油田の操業が難しくなることも考えられる。

\section{6. ロシアの現状}

ロシアの $\mathrm{CO}_{2}$ 排出量は世界の $15 \%$ を占める。

図 12 はロシアのガス産業分野における温暖化ガス の排出量を示す (IEAレポート「Optimising Russian Natural Gas - Reform and Climate Policy」2006)。

石油随伴ガスのフレア量は $15 \mathrm{BCM}\left(\mathrm{CO}_{2}\right.$ 換算 44 百万 トン）と推定されており，フレアの比率は $27 \%$ である。 実際のフレア量はもつと多いと考えられており，サテラ

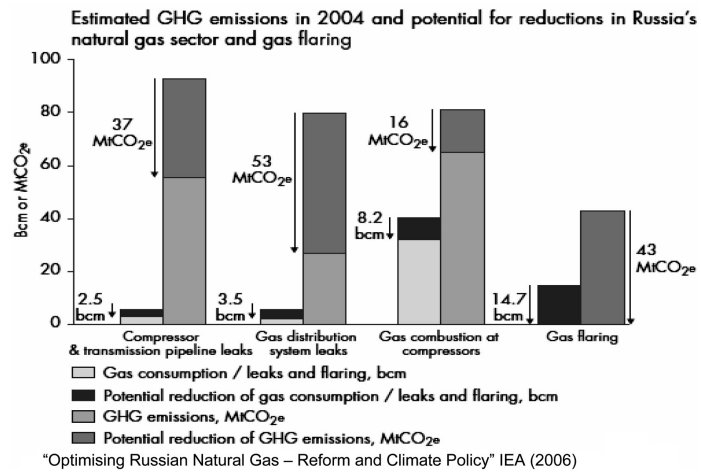

図 12 ロシアの温暖化ガス排出

イト画像の処理によって $60 \mathrm{BCM}$ (暫定値) という数值 も得られている。いずれにしても大量のガスがフレアさ れており削減の余地は大きい。ロシアではこれ以外に, 幹線パイプライン・支線パイプラインから合わせて 11.5 $\mathrm{BCM}\left(\mathrm{CO}_{2}\right.$ 換算 173 百万トン $)$ のガスが漏洩し，また， パイプライン昇圧コンプレッサーの燃料に $41 \mathrm{BCM}$ もの ガス $\left(\mathrm{CO}_{2}\right.$ 換算 82 百万トン $)$ を消費している。

石油会社が生産する随伴ガスの利用が遅れているの は, Gazprom が所有するガスパイプラインの利用権が 得られない, ガスパイプラインを自前で建設するには ガス販売価格が安すぎる, マーケットまでの距離が遠 すぎて採算性が合わない, ガス圧入に適した油田が見 つからないなどの理由が挙げられる。一方で, KhantyMansijsyk 自治区で操業し一番多く随伴ガスを生産して いる Surgutneftegas 社のフレア率は7\%であり，ガスの 有効利用が進んでいる。今後さらに GGFR の支援を受け て世界銀行の炭素基金を利用したフレア削減プロジェク 卜を計画しており，ほかの石油会社の手本となっている。

パイプラインについてはメンテナンス不足や老朽化 が，コンプレッサーについては効率の悪い旧式のものを 使用していることが原因であり，いずれも改善の余地は 大きい。削減可能量はそれぞれ $6 \mathrm{BCM}, 8 \mathrm{BCM}$ と推定さ れている。Gazprom はロシアのガス生産の $90 \%$ を占め, すべての幹線パイプラインを所有し，支線パイプライ ンネットワークの $3 / 4$ をコントロールしている。しかし ながら今まで, 輸出能力の拡大に向けて大型の新規プロ ジェクトを優先し, 既存インフラの整備, ガス利用の効 率化をおろそかにしてきた。また国内需要の伸びが予測 される中, 既存の巨大ガス田は減退を始めており, 供給 不足問題にも直面している。

ガスの節約可能量はフレアガス削減を含めて年間 30 BCM, 温暖化ガスの削減量に換算すると 150 百万トンと 膨大な量になり，ロシアの石油会社にとっても外国の 投資家にとっても大きなビジネスチャンスへの期待が高 


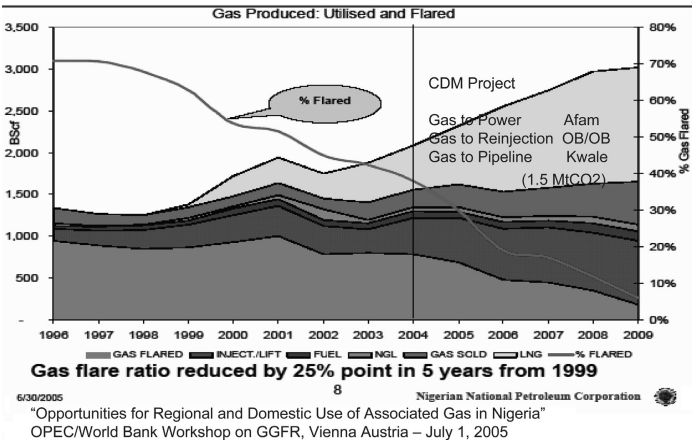

図 13 ナイジェリアのフレア削減プロジェクト

まっている。

\section{7. ナイジェリアの現状}

図 13 はナイジェリアにおけるフレアガス削減への取 り組みを示す (NNPCの発表「Opportunities for Regional and Domestic Use of Associated Gas in Nigeria」於 OPEC/ World Bank GGFR Workshop 2005)。

随伴ガス量は 1996 ～ 2004 年の間, $1,350 \sim 2,050$ BCF へ増加したが, フレアガスの比率は $70 \sim 40 \%$ へ減少し, 2004 年のフレア量は約 750 BCF (21 BCM) となってい る。フレアされていたガスはガス圧入・ガスリフト，自 家消費, NGL 生産, 外販, LNG 供給などの用途に使用 される。ナイジェリアはロシアと異なりすでにLNGの 輸出国（2006 年末現在，液化プラント能力 1,760 万トン / 年, 2007 年には 2,190 万トン / 年へ増加）であり, 今 後は LNG 供給ガスとしての用途が大きく伸びる見込み である。ナイジェリアには GTL プロジェクトも進行し ており，将来的には GTLの供給ガスとしての利用も期 待できる。フレアガスの比率は 2009 年に $10 \%$ 以下へ減 少させることが目標となっている。

本年 11 月, ベトナム RangDong プロジェクトに次ぎ, ナイジェリアにおいて世界で 2 番目のフレア削減 CDM プロジェクトが認定された。Kwale 油ガス処理プラント で発生する随伴ガスを 48 万 $\mathrm{KW}$ の発電能力を持つ卸電 力業者へ燃料ガスとして供給するもので，ナイジェリ アの不安定な電力事情の改善に寄与すると同時に，年間 1.5 百万トンの $\mathrm{CO}_{2}$ 排出削減になる。本プロジェクトは GGFR が支援しているデモプロジェクトのなかで，最初 にCDM の認定を受けたプロジェクトになった。

\section{8. 炭酸ガス地中固定への取り組み}

エネルギー起源の $\mathrm{CO}_{2}$ 排出量削減のためには, $\mathrm{CO}_{2}$ を大量に排出する施設, 特に火力発電所に CCS を採用 することが必要である。CCSへの関心が高い欧州には,
Zero Emission Fossil Fuel Power Plants（ZEP）と呼ばれる 産官学の取り組みがあり, 石油会社, 電力会社が実証 プロジェクト計画を発表している。しかしながらコスト 負担が大きいことから，国の強力な支援なしでは大幅な CCS の進展は困難と考えられている。現在, 世界で計 画中の実証プラントがすべて完成しても $\mathrm{CO}_{2}$ の地下隔 離量は 2015 年に 15 百万トンに留まる。一方, 政策の後 押しがうまくいけば，CCS は石炭資源を豊富に持つ国の 石炭火力発電所から進展し, 2030 年時点で世界の新設 の石炭火力発電所の $70 \%$, ガス火力発電所の $35 \%$ に設 置され, 合わせて 20 億トンの $\mathrm{CO}_{2}$ の排出が削減される とするシナリオも想定されている。(IEA World Energy Outlook 2006)。

図 14 は CCS を巡る最近の動向を示す。

Carbon Sequestration Leadership Forum (CSLF) は, 炭 素隔離の研究・開発を促進するための国際的な協力枠組 みで, 2002 年に設立された。米国, カナダ, 英国, ドイツ, フランス, イタリア, オランダ, ロシア, 日本, 韓国, 豪州等 21 ヶ国と ECがメンバーである。中東産油国か らは唯一サウジアラビアが参加している。2005 年に刊 行された IPCC 特別報告書では, CCS は温暖化ガス削減 に大きく寄与する技術オプションの 1 つと位置づけら れ，近年，CCS を巡る議論が活発化してきている。

Gleneagles G8 Summit では CCS の開発および商業化の 加速が要請され, 行動計画のなかに石炭火力への CCS 適用可能性検討が盛り込まれた。

アジア太平洋パートナーシップ (APP) は, 排出削減 義務を負わずに企業活力の活用, エネルギ一技術協力に よって $\mathrm{CO}_{2}$ の排出削減を目指す取り組みで, 米国, 豪 州, 中国, インド, 日本, 韓国がパートナーとなって設 立された。セメント, 石炭, 鉄鋼, 発電等の分野をカバー する 8 つタスクフォースが組織され，CCS はクリー ン化石燃料タスクフォースのなかで取り扱われている。 OPEC も CCS に関心を寄せており, CCS のシンポジウム

- Carbon Sequestration Leadership Forum (CSLF) 第一回会議開催 (2003 年 6 月)

- Gleneagles G8 Summit (2005 年 8 月)

「CCS の開発および商業化の加速を要請」

- Asia Pacific Partnership (APP) (2006 年 1 月)

Task Force 1: Clean Fossil Energy

- Symposium on Carbon Management (2006 年 5 月)

Saudi Aramco が主催

- IEA - CSLF Workshop (2006 年 8 月) $\lceil\mathrm{CCS}$ は始動, より多くの商業実証プラントが必要」

・ロンドン条約締約国会議（2006 年 10 月） 海洋投棄可能な廃棄物に $\mathrm{CO}_{2}$ を追加

図 14 炭素隔離を巡る最近の動向 
が Saudi Aramco 主催によりサウジアラビアで開催され たことは注目に值する。

CSLF と IEA の共催ワークショップでは，(1)技術，(2) 商業化・資金援助, (3)政策・規制, (4)社会認知, (5)国 際メカニズムについて検討すべき論点や課題の整理が 行われた。現段階では CCS に対する社会的認知度は低 く, また, 世界野生生物財団やグリンピースなどの環境 NGO は, CCS は化石燃料の使用を増加させるとの理由 から反対を表明している。廃棄物の海洋投入処分は海洋 污染防止を図るロンドン条約で規制されているが，2006 年 11 月に開かれたロンドン条約締約国会議において, 投棄可能な廃棄物に $\mathrm{CO}_{2}$ を追加する案を欧州諸国など が提案し採択された。これにより $\mathrm{CO}_{2}$ の地下廃棄に向 けての法的整備が進んだ。

一方，ケニアで開催された地球温暖化防止条約締約国 会議 COP12 / MOP2 では, $\mathrm{CO}_{2}$ の地下廃棄に伴う排出権 獲得を認めるかについて議論されたが結論をだすことが できず, 2 年後に先送りされた。 $\mathrm{CO}_{2}$ の漏洩, 排出権価 格の下落の恐れなどを理由にブラジルなど南米諸国，島 しょ国などが反対したためであり，国際的に足並みを揃 えることの難しさを見せつけられる結果となつた。

CCSの発展のためには実証事例を増やし，これらの問 題点の解決策を示していくことが大事である。 $\mathrm{CO}_{2} \mathrm{EOR}$ プロジェクトは油層条件が適していれば採算性の向上が 期待できるため，石油開発会社は CCS の事例を増やし， 技術，経済，安全面に関する知見を増加させることに貢 献できるであろう。

\section{9. 炭酸ガス地中固定既存プロジェクト}

現在，世界で CCSが行われているのは石油ガスの開 発現場であり，ノルウェーの Sleipner ガス田（1996 年開 始), カナダの Weyburn 油田 (2000 年開始), アルジェ リアの In-Salah ガス田（2005 年）の 3 箇所を数えるの夕 である。(In-Salah の CCS プロジェクト総投資額は 500 million US\$）年間圧入量はそれぞれ 100 万トン, 180 万 トン, 115 万トンで，合計圧入量は 50 万 $\mathrm{Kw}$ の石炭火力 発電所からの排出量に相当する。いずれのプロジェクト も，国際共同研究開発プロジェクトに指定されている。

図 15 は Weyburnの実績を示す。 $\mathrm{CO}_{2}$ 圧入量 (2005 年末) は 150 mmscfd で，圧入量の $33 \%$ はリサイクル分。米国 ダコタ州の石炭ガス化プラントから回収された $\mathrm{CO}_{2}$ （純 度 $95 \%$ ）が圧入されており，購入コストは 70 c/ 1000 cf（12\$/ton）と見られている（非公式情報）。2005 年, Apache 社も同社から $\mathrm{CO}_{2}$ を購入し, 近隣の Midale 油田 へ圧入を開始した。圧入量は 26 mmscfd（2006 年）が見 込まれている。

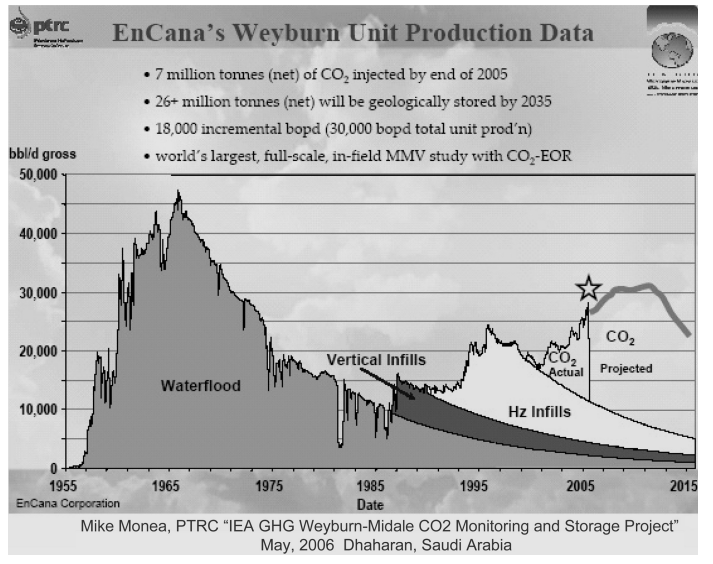

図 15 EnCana's Weyburn Unit Production Data

Weyburn 油田では原油生産回復効果が顕著に見 られる。1995年, 当油田のオペレーターであった PanCanadian（現 EnCana）は，当油田での $\mathrm{CO}_{2} \mathrm{EOR}$ プロ ジェクト実施の意思を固めていた。当時の油価は $19 \$$ / bbl（WTI 原油先物価格）であったが, 油価が大幅に上 昇した現在, 本プロジェクトの採算性も大きく向上し ていると想像される。 $\mathrm{CO}_{2} \mathrm{EOR}$ は第一次オイルショック 後ブームを迎えたが，その後油価の沈静化とともにし ぼんでしまつた。現在の油価が今後とも維持されるとの 見通しが立てば，カナダ，アメリカで枯渴油田における CCSEOR プロジェクトが進展することが期待できる。圧 入モニタリング報告書によれば，地表への漏洩の可能 性はほぼゼロと報告されている（IEA GHG Weyburn $\mathrm{CO}_{2}$ Monitoring \& Storage Project Summary Report 2000-2004, PTRC)。

カナダは石炭資源にも恵まれており, カナダの石炭 生産企業, 石炭火力発電事業者および米国の Electric Power Research Institute が Canadian Clean Power Coalition（CCPC）を組織し， CCS を含むクリーンコール 技術の研究を行っている。CCPC のメンバーであるサス カチュアン州の Saskpower は CCS 実証プロジェクト計 画を推進している（2012 年操業開始予定）。

\section{0. 炭酸ガス地中固定予定プロジェクト}

図 16 は現在計画中の石油ガス関連の $\mathrm{CO}_{2}$ 地中固定プ ロジェクトを示す。

Miller プロジェクトは, 北海ガス田のガスから水素を 製造して，スコットランドに建設する 35 万 $\mathrm{Kw}$ の水素火 力発電所の燃料とし, 派生する $\mathrm{CO}_{2}$ は北海の枯渇油田で ある Miller 油田に地下固定 (CCSEOR) するもの。事業者 は BP, 総事業費は 6 億ドル。2009 年の操業開始を目指す。 Carson プロジェクトはカリフォルニアの製油所のコーク 

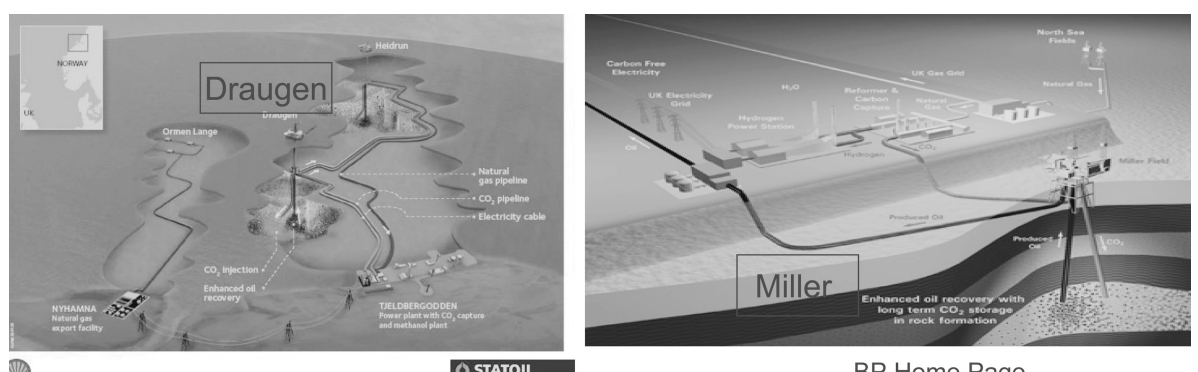

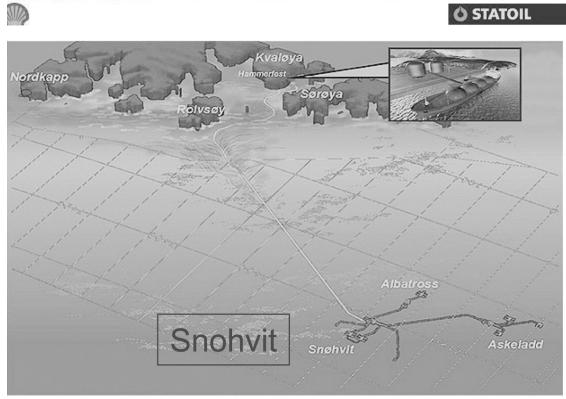

Statoil Home Page

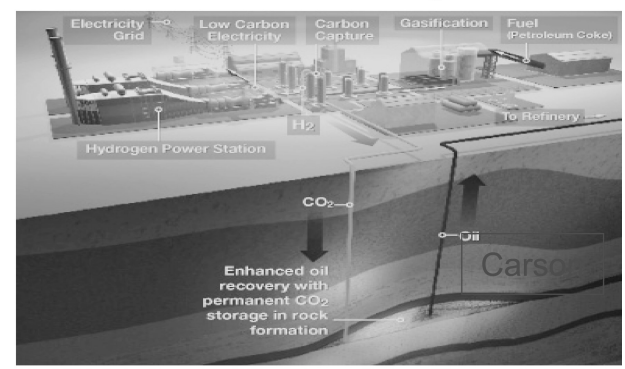

BP Home Page

図 16 炭素隔離プロジェクト（進行中）

から水素を製造して，新たに建設される 50 万 $\mathrm{Kw}$ の水素 火力発電所の燃料とし, 派生する $\mathrm{CO}_{2}$ は近隣の枯渇油田 に地下固定 (CCS EOR) するもの。事業者は $\mathrm{BP}, \mathrm{CO}_{2}$ 固 定量は 4 百万トン / 年, 総事業費は 10 億ドル, 2011 年 の操業開始を目指す。これらのプロジェクトは水素化社 会の到来も睨んだ，石油ガスの開発と環境保全の両立を 目指す新しい時代への挑戦といえるであろう。

Draugen プロジェクトは，バレンツ海ガス田のガスを 使用するノルウェーのガス火力発電所とメタノール生産 工場から排出される $\mathrm{CO}_{2}$ を回収し, Draugen 油田に地下 固定 $\left(\mathrm{CO}_{2} \mathrm{EOR}\right)$ するもの。事業者は Shell/Statoil, $\mathrm{CO}_{2}$ 固 定量は 2 ～ 2.5 百万トン/年, 2011 年の操業開始を目指す。

Snohvit プロジェクトは Snohvit ガス田の LNG 液化プ ラントで分離回収される $\mathrm{CO}_{2}$ を, 同ガス田の水層に地 下固定するもので，事業者は Statoil。

Gorgon プロジェクトは豪州の Gorgon ガス田の LNG 液化プラントで分離回収される $\mathrm{CO}_{2}$ を, 同ガス田の水 層に地下固定するもので，事業者は Shell。

Miller プロジェクトと Draugen プロジェクトは前述 の ZEP プログラムに含まれており，ZEPには発電事業 者によるドイツやポーランドでの石炭ガス化複合発電 (IGCC) 発電所建設計画も含まれている。

石油ガス関連の CCS プロジェクトの多くが欧州で計 画されており，また，これを実施する事業者も欧州の IOC が多い。EUは $\mathrm{CO}_{2}$ の大規模排出施設に強制的な排 出枠（約 22 億トン）を設け，2005 年 1 月からキャップ \&トレード方式の排出権取引制度を実施していることが
その背景にある。

\section{1. 地球温暖化対策への国際的取り組み}

京都メカニズムの 1 つである Clean Development Mechanism (CDM) は, 先進国と途上国の事業者が共同 で温室効果ガスの削減プロジェクトを途上国で実施し, そこで生成した削減分を炭素クレジットとして事業者が 獲得できる制度である。地球温暖化対策への国際的取り 組みの 1 つとして重要な役割を担っており，2006 年末 現在, 承認されているCDM プロジェクトは 467 件, 総 削減量は 107 百万トン/年に達している。プロジェクト のタイプからみると, 再生可能エネルギー利用発電事業, バイオマス発電事業, ごタ処理場からのメタン回収事業, 省エネのプロジェクトがほとんどである。フレア削減 プロジェクトはベトナムとナイジェリアでのプロジェク ト 2 件が承認されているのみで, $\operatorname{CCS}$ は 2 件申請されて いるが未承認である。その 1 つはべトナムの天然ガス火 力発電所から排出される $\mathrm{CO}_{2}$ を回収し, White Tiger 油 田に地下固定するもの (CCSEOR) で, $\mathrm{CO}_{2}$ 固定量は 7.7 百万トン / 年。もうひとつはマレーシアの LNG 液化プ ラントで分離回収される $\mathrm{CO}_{2}$ を沖合いの地下の水層に 固定するもので, $\mathrm{CO}_{2}$ 固定量は 3 百万トン/年。いずれ も日本の企業が提案している。

フレア削減とCCS プロジェクトは温室効果ガスの削 減に大きく寄与することから, CDM プロジェクトの増 加が望まれる。フレア削減プロジェクトについては, 認 定プロセスの迅速化, CCS プロジェクトについては方法 
論の早期採用が期待される。

世界最大の Ghawar 油田の今後の生産能力の推移は, 世界の石油生産能力のピーク時期を占う鍵の 1 つとして 関心を集めている。IEA World Energy Outlook 2006 の基 準シナリオでは 2010 年頃, 日量約 6 百万バレルのレベ ルに達してピークを迎えると想定されている。

本油田の原始埋蔵量は約 3,000 億バレルと推定さ れ，2005 年 1 月現在，既生産量 610 億バレル（回収率 $20 \%$ ), 残存確認埋蔵量 650 億バレル，推定可採埋蔵量 250 億バレルである（究極回収率 $50 \%$ ）。主要生産エリ アである Ain Dar/Shedgum 地区に限ると回収率はすでに $40 \%$ に達し, 残存確認埋蔵量生産時点で $60 \%$ に達する。 究極回収率は $75 \%$ を想定している。このような高い回 収率の達成のためには第三次回収が不可欠であり, 近い 将来, CCS EOR の適用が発表されるようなことがある かもしれない。石油開発の進展と環境保全の両立を目指 すプロジェクトが産消協力事業として立ち上がり，エネ ルギー問題への画期的な国際的取り組みになることを期 待したい。

Nicholas Stern（元世界銀行主席エコノミスト，現英国 政府経済顧問）の温暖化対策報告書（The Economics of Climate Change）が 10 月末に発表され反響を呼んでいる。 経済モデル計算の結果によると, 深刻な地球環境破壊が もたらす経済損失は毎年少なくとも世界の GDP の $5 \%$ に達し，地球温暖化の影響を広く捉えると $20 \%$ にもな る。一方, 大気中の $\mathrm{CO}_{2}$ 濃度を $500 \sim 550 \mathrm{ppm}$ で安定さ せ，地球温暖化がもたらすリスクを軽減するのに必要な コストは GDP の約 1\%である。この温暖化対策コスト は世界経済にマイナスの影響を与える恐れもあるが，一 方，温暖化対策の新技術，サービスを提供する市場を創 生し，世界経済の発展に寄与する可能性もある。そして 温暖化対策には国際的な取り組みが不可欠であり，その ためには国際的な排出権取引と技術開発協力が重要とし ている。

米国では温暖化対策としてはAPPなどの自主的取り 組みや技術開発が中心で, 京都議定書への復帰は考え られていない。しかしながら，大気污染の増大，熱波襲 来の深刻化, 山火事の増加, 降雪量・水資源減少のリス クなどを抱えているカリフォルニア州は，2006 年 9 月， GHG 排出削減法案に署名し, 2007 年 1 月, 法案は発効 する。2020 年までに排出量を現在のレベルから $25 \%$ 削 減して 1990 年のレベルへ戻すことを目標としている。 このため英国との間で排出権取引協力協定が締結され た。カリフォルニア州以外にも 28 州がなんらかの気候 変動行動計画を策定しており，排出量取引を前提とした 州レベルでの削減義務化への取り組みも進展している。
このように地球環境保全への意識は国の立場を超えて共 通の意識として広がり, 国際協力の土台が築きあげられ つつある。

CCS の進展には排出規制が導入されること, 排出量取 引により $\mathrm{CO}_{2}$ 排出コストが明示されることが重要な条件 となる。このような条件が整うまでには相当な時間を要 するであろうが, 石油ガスの開発と環境保全の両立を目 指す石油開発会社の新しい時代への挑戦はすでに始まつ ている。

\section{参 考 文 献}

1) Sakhalin Energy Investment Company Home Page, http : //www.sakhalinenergy.com/en/.

2) EIA Annual Energy Outlook 2006

3) Canada's Energy Outlook : The Reference Case 2006, http : //www.nrcan-rncan.gc.ca/inter/publications/ peo_e.html.

4) Suncor Annual Report 2005.

5) IEA World Energy Outlook 2006.

6) Global Gas Flaring Reduction Partnership (GGFR) Home Page.

7) “Optimising Russian Natural Gas - Reform and Climate Policy 2006” IEA.

8) First Regional Symposium on Carbon Management, Carbon Management Challenges and Opportunities for the Petroleum Industry, May 22-24, 2006 Dhahran, Saudi Arabia, http : //www.co2management.org/images/ top_image_symposium_prog.jpg.

9) Carbon Sequestration Leadership Forum (CSLF) Home Page.

10) Angel Sainz "The European Perspective" IEA- CSLF Workshop, San Francisco, USA Aug, 2006.

11) IEA GHG Weyburn $\mathrm{CO}_{2}$ Monitoring \& Storage Project Summary Report 2000-2004, PTRC.

12) IPCC Third Assessment Report - Climate Change 2001.

13) Clean Development Mechanism; http//cdm.unfccc.int/.

14) Stern Review on the economics of climate change, http : //www.hm-treasury.gov.uk/independent_reviews/ stern_review_economics_climate_change/ stern_review_report.cfm.

15) Fifty-Year Crude Oil Supply Scenarios : Saudi Aramco's Perspective, Feb 24, 2004.

CSIS, Washington D.C.

16) Our Changing Climate, Assessing the Risks to California, http : //www.climatechoices.org/site/ourchanging-climate.html. 